\title{
EFFECTIVE REGULATION OF DUAL DISTRIBUTION: A ROBINSON-PATMAN APPROACH
}

\begin{abstract}
The increasingly widespread implementation of dual distribution as a production-distribution technique, coupled with a heightened awareness of the potential for competitive abuse inherent therein, has provided impetus to the search for means by which this practice may effectively be regulated. This comment considers whether the price discrimination provisions of the Robinson-Patman Act might be the appropriate vehicle through which such regulation could be effectuated.
\end{abstract}

$\mathrm{H}$

ISTORIGALIY, the independent distributor has been considered the keystone of the production-distribution chain. ${ }^{1}$ In return for a trade discount he has served as a middleman between the manufacturer and retailer, assuming bulk storage, sale, and delivery functions for the former and extending credit to the latter. ${ }^{2}$ The danger of antitrust prosecution inherent in accretions by horizontal, conglomerate, and vertical acquisitions, ${ }^{3}$ coupled with the increased need for more efficient, less costly, methods of operation has, however, generated a trend towards assimilation of these functions ${ }^{4}$ through vertical inte-

\footnotetext{
${ }^{2}$ See Rowe, The Evolution of the Robinson-Patman Act: A Twenty-Year Perspective, 57 Colum. L. Rev. 1059, 1061 (1957).

IId.

${ }^{8}$ See, e.g., FTC v. Proctor \& Gamble Co., 386 U.S. 568 (1967); Brown Shoe Co. v. United States, 370 U.S. 294 (1962); United States v. Columbia Steel Co., 394 U.S. 495, 536 (1948); United States v. Swift \& Co., 286 U.S. 106, 116 (1932); United States v. General Dynamics Corp., 258 F. Supp. 36, 60 (1966); cf. FTC v. Consolidated Foods Corp., 880 U.S. 592 (1965).

'See, e.g., Dayco Corp. v. FTC, 362 F.2d 180 (6th Cir. 1966) (jobbers assimilate wholesale function); Joseph A. Kaplan \& Sons v. FTC, 347 F.2d 785 (D.C. Cir. 1965) (retailer assimilates wholesale function); Reines Distribs., Inc. v. Admiral Corp., 256 F. Supp. 581 (S.D.N.Y. 1966) (manufacturer assimilates wholesale function). Vertical integration was recognized in the oil industry as early as 1931, see United States v. Standard Oil Co., 47 F.2d 288, 309.11 (1981), and in the steel industry as early as 1920, see United States v. United States Steel Corp., 251 U.S. 417 (1920). See generally Hale, Vertical Integration: Impact of the Antitrust Laws Upon Combinations of Successive Stages of Production and Distribution, 49 Colum. L. REv. 921, 928-36, 950.51 (1949). See also Doubleday \& Co., 52 F.T.C. 169, 208 (1955): "Wholesalers and retailers no longer comprised clean-cut separate links between the producer and the ultimate consumer, each responsible for a clearly defined set of duties. Marketing functions became scrambled, with many permutations and combinations. Many jobbers and brokers contributed genuine and important services, though assuming only part of the traditional full-time wholesaler's job. More often there was the contrary trend toward integration of distributive functions. Manufacturers created their own outlets. Retailers integrated into wholesaling, and wholesaling into retailing, either by outright "ownership or by cooperative arrangements. The number of patterns was legion and
} 
gration."

One product of such integration by manufacturers has been

diverse."; Subcomm. No. 4 of the House Salect Comm. on Small Business, The Impact Upon Small Business of Dual Distribution and Related Vertical Integration, H.R. REP. No. 1943, 88th Cong., $2 d$ Sess. 5 (1964); Rowe, supra note 1, at I061.

-Vertical integration has been variously defined as "the coordination of successive steps of production or distribution," Kessler \& Stern, Competition, Contract, and Vertical Integration, 69 YALE L.J. 1 (1959), or "unified control of more than one successive stage in the production or distribution of goods and services," Hale, supra note 4 , at 921 . When the term vertical integration is used hereafter that form known as ownership integration will be intended unless expressly designated otherwise. Ownership integration, as the term implies, means the nonacquisitional assimilation by outright ownership of a stage of production or distribution other than that in which the acquiring company had been engaged. For purposes of analysis there shall be two types of vertical integration, "ascending" and "descending," the former being the assimilation of an earlier function, e.g., assimilation by a retailer of the wholesale function, and the latter the assimilation of a later function.

There are other methods by which integration may be effected, all of which involve some degree of control short of outright ownership: by contract, see Kessler \& Stern, supra at 3-21; exclusive dealing arrangements, United States v. Yellow Cab Co., 69 F. Supp. 170, 174 (N.D. III. 1946), rev'd, 332 U.S. 218 (1947); fair trade statutes, which legalize retail price maintenance, e.g., Miller-Tydings Amendment, 15 U.S.C. $\$ 1$ (1964); threat of refusal to deal or renew a franchise with those who fail to conform to certain policies, see United States v. Colgate \& Co., 250 U.S. 300 (1919). But see George W. Warner \& Co. v. Black \& Decker Mfg. Co., 277 F.2d 787, 790 (2d Cir. 1960); by creation of subsidiaries which, though made to appear independent, are in fact controlled by the parent, see Baim \& Blank, Inc. v. Philco Corp., 148 F. Supp. 541 (E.D.N.Y. 1957).

While there has been considerable litigation over ascending integration by retailers of the wholesale function and by manufacturers of the primary materials sources, the focus of this comment, because of the nature of the problem considered, will be descending integration by the manufacturer through assimilation of the wholesale function.

Vertically integrated firms are, of course, not strangers to the antitrust laws, for they have frequently been found guilty of activities proscribed by $\S 1$ of the Sherman Act, 15 U.S.C. $\$ 1$ (1964). See FTC v. Motion Picture Advertising Serv. Co., 344 U.S. 392, 395 (1953); United States v. Columbia Steel Corp., 334 U.S. 495 (1948); United States v. Paramount Pictures, Inc., 334 U.S. 131 (1948); United States v. Yellow Cab Co., 392 U.S. 218 (1947); United States v. Swift \& Co., 286 U.S. 106, 116 (1932); United States v. Lehigh Valley R.R., 254 U.S. 255, 269-70 (1920); United States v. Reading Co., 253 U.S. 26, 57 (1920); United States v. American Tobacco Co., 221 U.S. 106 (1911); Standard Oil Co. v. United States, 221 U.S. 1 (1911); United States v. Great At1. \& Pac. Tea Co., 67 F. Supp. 626 (E.D. Ill. 1946), aff'd, 173 F.2d 79 (7th Cir. 1949). See generally Adelman, Integration and Antitrust Policy, 63 HArv. L. REv. 27 (1949); Adelman, Effective Competition and the Antitrust Laws, 61 Harv. L. REv. 1289, 1314-21 (1948); Hale, supra note 4; Kessler \& Stern, supra. Similarly, the vertically integrated firm has been found guilty of violating $\$ 2$ of the Sherman Act, I5 U.S.C. $\$ 2$ (1964), see United States v. Griffith, 334 U.S. 100, 107 (1948); United States v. Columbia Steel Corp., supra; United States v. Paramount Pictures, Inc., supra; United States v. Lehigh Valley R.R., supra; United States v. American Tobacco Co., supra; Standard Oil Co. v. United States, supra; $\$ 3$ of the Clayton Act, 15 U.S.C. $\$ 3$ (1964), see Standard Oil Co. v. United States, 337 U.S. 293, 314 (1949); $\$ 7$ of the Clayton Act, 15 U.S.C. $\$ 18$ (1964), see FTC v. Procter \& Gamble Co., 386 U.S. 568 (1967); Brown Shoe Co. v. United States, 370 U.S. 294 (1962); United States v. E. I. duPont de Nemours \& Co., 353 U.S. 586 (1957); Trans World Airlines, Inc. v. Hughes, 
the development of dual distribution, ${ }^{8}$ a novel distributive technique by which the manufacturer sells its product to independent wholesale distributors while simultaneously competing with those purchasers through its own division distributors. Though such a relationship yields certain economic advantages to the manufacturer, ${ }^{7}$ the inherent opportunities for abuse would seem apparent. ${ }^{8}$ By favoring its own division, the manufacturer can reduce the competitiveness of its independent distributors, an approach which in turn may deny

332 F.2d 602 (2d Cir. 1964); Reynolds Metals Co. v. FTC, 309 F.2d 223 (D.C. Cir. 1962); and $\$ 5$ of the Federal Trade Commission Act, 15 U.S.C. $\$ 45$ (1964), see FTC v. Motion Picture Advertising Serv. Co., supra.

- Dual distribution has received congressional attention since 1953. See generally Staff of Senate Select Comm. on Small Business, 83d Cong., 2d Sess., Problems of Independent TIRE DeAlers (Comm. Print 1953); Hearings Before a Subcomm. of the Senate Select Comm. on Small Business, Competitive Problems of Independent FlatGlass Dealers, 85th Cong., 2d Sess. (1958); Senate Select Comm. ON Small Business, Studies of Dual Distribution: The Flat-Glass Industry, S. Rep. No. 1015, 86th Cong., 1st Sess. (1959); Senate Select Comm. on Small Business, Ninth Annual REPORT, S. REP. No. 6, 86th Cong., lst Sess. (1959); S. 2640, 87th Cong., Ist Sess. (1961); S. 2641, 87th Cong., lst Sess. (1961); S. 1107, 88th Cong., 1st Sess. (1963); S. 1108, 88th Cong., Ist Sess. (1963); H.R. 3559, 88th Cong., lst Sess. (1963); H.R. 3562, 88th Cong., 1st Sess. (1963); Hearings Before Subcomm. No. 4 of the House Select Comm. on Small Business, The Impact Upon Small Business of Dual Distribution and Related Vertical Integration, 88th Cong., lst Sess. (1963); S. 1842, 89th Cong., 1st Sess. (1965); S. 1843, 89th Cong., 1st Sess. (1965); S. 1844, 89th Cong., Ist Sess. (1965).

“'Dual Distribution' exists when a vertically integrated firm operates in two successive stages of production and/or distribution of a good but also sells some of its output from the first stage to independent firms who then sell in competition with the supplying firm's second stage operations. Thus the independent is in competition with his supplier." Subcomm. No. 4 of the House Select Comm. ON SMall Business, The Impact Upon Small Business of Dual Distribution and Related Vertical 1Ntegration, H.R. Rep. No. 1943, 88th Cong., 2d Sess. (1964).

Despite a lack of significant judicial recognition, it would appear that dual dis. tribution has achieved recognition as a competitive distribution technique in a significant number of industries. In hearings before a congressional committee representatives of more than forty-five different industries testified to the existence of dual distribution and the anticompetitive effects created by its abuse. See Hearings Before Subcomm. No. 4 of the House Select Comm. On Small Business, supra.

'It is generally recognized that there are certain efficiencies inherent in vertical integration: increased stability of operations resulting from greater coordination; facility of long range planning due to uniformity of the quality of consumer outlets and sources of supply; use maximization of plant, equipment, inventory, and personnel; and reduction of transfer costs. See Kessler \& Stern, supra note 5, at 4-8.

${ }^{8}$ Cf. FTC v. Procter \& Gamble Co., 386 U.S. 568 (1967); Brown Shoe Co. v. United States, 370 U.S. 294 (1962); Reynolds Metals Co. v. FTC, 309 F.2d 223 (D.C. Cir. 1962); United States v. Aluminum Co. of America, 148 F.2d 416 (2d Cir. 1945); Kessler \& Stern, supra note 5, at 14: "[T] point may not prove consonant with the optimum allocation of goods and services in the economic and social system as a whole." See generally, D. BAUM, The RobinsonPATMAN ACT xiii-xvii (1964). 
smaller competing manufacturers who are unable to integrate an efficient, stable avenue of distribution. ${ }^{9}$ Moreover, the lack of sound distribution outlets may impede entry into the market by potential competitors. ${ }^{10}$ Thus by squeezing the independent wholesale distributor, the integrated manufacturer creates a lever which can be used to ensure a desired share of the market at both the primary and secondary levels. ${ }^{11}$

This abuse of the distribution technique can effectively be eliminated under the Sherman Act ${ }^{12}$ if the market control actually achieves or is intended to achieve monopolistic proportions, ${ }^{13}$ regard-

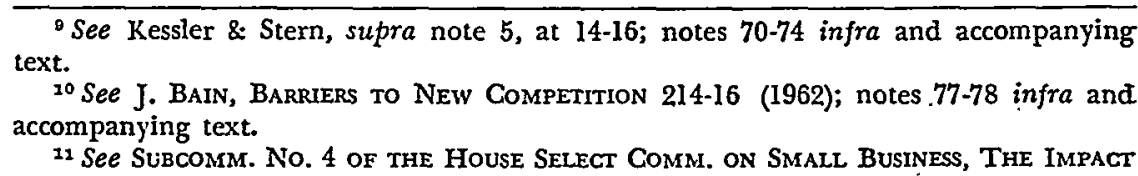
Upon SMall Business of Dual Distribution and Related Vertical Integration, supra note 6 , at 6-10.

${ }^{12}$ See 15 U.S.C. $\$ \$ 1-2$ (1964).

${ }^{23}$ See United States v. Aluminum Co. of America, I48 F.2d 416 (2d Cir. 1945). Although many cases can be cited for the proposition that a corporation can be guilty of an intercorporate conspiracy with its own subsidiaries, see Timken Roller Bearing Co. v. United States, 341 U.S. 593 (195I); Kiefer-Stewart Co. v. Joseph E. Seagram \& Sons, 340 U.S. 211 (195I); United States v. Yellow Cab Co., 332 U.S. 218 (1947); United States v. General Motors Corp., 121 F.2d 376 (7th Cir.), cert. denied, 314 U.S. 618 (194I), there is only one case which states, without explanation, that a division is incapable of an intracorporate conspiracy with the corporation of which it is a part, Deterjet Corp. v. United Aircraft Corp., 211 F. Supp. 348, 354 (D. Del. 1962). The decision is based on a series of cases which hold that a corporation cannot conspire with its officers or agents. See Mackey v. Sears, Roebuck \& Co., 237 F.2d 869 (7th Cir. 1956), cert. dismissed, 355 U.S. 865 (1957); Nelson Radio \& Supply Co. v. Motorola, Inc., 200 F.2d 911 (5th Cir. 1952), cert. denied, 345 U.S. 925 (1953). It would appear, however, that the analogy to corporate subsidiary cases, supra, where conspiracies have been found, may be more compelling since the difference between division and subsidiary status is largely one of form. See, e.g., Reines Distribs., Inc. v. Admiral Corp., 256 F. Supp. 581 (S.D.N.Y. 1966).

The Deterjet result, however, may, in the ultimate analysis, be preferable, but for reasons not set forth in the opinion. It has been argued that the courts will find no conspiracy possible between a division and the corporation of which it is a part since to do so would subject the corporation to a number of per se rules which introduce injurious inflexibility into intracorporate relationships. Moreover, it may be felt that application of $\S 1$ would usurp the function of $\$ 2$ which is designed to deal with the single enterprise. See Kessler \& Stern, supra note 5, at 90 . The availablity of this alternative source of regulation may well encourage further acceptance of the Deterjet rule.

However, such a result need not compel the conclusion that since a division cannot conspire it cannot be a purchaser for purposes of the Robinson-Patman Act. It would seem improbable that a ruling used to enhance the practical efficacy of antitrust regulation on the one hand could be used as the sole basis for frustrating it on the other. Moreover, the absence of an alternative provision which explicitly covers dual distribution would appear to militate against acceptance in a RobinsonPatman context of the conclusion reached in intracorporate conspiracy cases. 
less of whether the vertical integration which makes the dual distribution possible is acquisitional or nonacquisitional.14 Moreover, such anticompetitive conduct may be proscribed in its incipiency under section 7 of the Clayton Act ${ }^{15}$ if the integration is acquisitional. ${ }^{10}$ Beyond the purview of these provisions, however, are those situations in which dual distribution, effected through nonacquisitional integration, has not achieved monopolistic proportions. The apparent increase in dual distribution achieved through such nonacquisitional integration coupled with the pervasiveness of the resulting abuse has created a need for effective control in these instances as well.17 While legislative solutions have been proposed, ${ }^{18}$ little consideration has been given to the possibility that the problem may adequately be resolved within the context of existing antitrust regulation. Consequently the focus of the following analysis is to determine whether such control may effectively be achieved through the price discrimination provisions of the Robinson-Patman Act.

See generally 6A A. CoRbIN, Conrracrs \$1417 (1962); Adelman, Integration and Antitrust Policy, 61 HARv. L. REv. 27, 50-53 (1949); Adelman, Effective Competition and the Antitrust Laws, 61 HARv. L. REv. 1289, 1312-22 (1948); Kessler \& Stern, supra, note 5, at 89-90; Kramer, Does Concerted Action Solely Between a Corporation and Officers Acting on Its Behalf in Unreasonable Restraint of Interstate Commerce Violate Section 1 of the Sherman Act?, 11 FED. B.J. 130 (1951); Rahl, Conspiracy and the Anti-trust Laws, 44 Inc. L. REv. 743, 766 (1950); Comment, 53 Nw. U.L. Rev. 253, 256 (1958); Note, 100 U. PA. L. REv. 1006, 1009-12 (1952).

14 See note 5 supra.

1515 US.C. $\$ 18$ (1964).

16 See Brown Shoe Co. v. United States, 370 U.S. 294 (1962).

${ }^{2 \pi}$ See, e.g., Hearings Before Subcomm. No. 4 of the House Select Comm. on Small Business, The Impact Upon Small Business of Dual Distribution and Related Vertical Integration, supra note 6, at 1581-87.

${ }^{18} 15$ U.S.C. $\$ \& 2$ (a) (d), (e) (1964). Several amendments to Robinson-Patman have been proposed under which dual distribution could be regulated. S. 2640, 87th Cong., Ist Sess. (1961); S. 2641, 87th Cong., 1st Sess. (1961); S. 1107, 88th Cong., 1st Sess. (1963); S. 1108, 87th Cong., 1st Sess. (1968); H.R. 3559, 88th Cong., 1st Sess. (1963); H.R. 3562, 88th Cong., Ist Sess. (1963); S. 1842, 89th Cong., 1st Sess. (1965); S. 1848, 89th Cong., Ist Sess. (1965); S. 1844, 89th Cong., 1st Sess. (1965).

It should be noted, however, that, although the drafters of the proposed legislation in presentation to Congress stipulated that the Robinson-Patman Act in its present form is not capable of dealing with dual distribution, 111 CoNG. REc. 8,432 (daily ed. April 28, 1965) (remarks of Representative Roosevelt); 111 CoNG. REc. 8,542 (daily ed. April 28, 1965) (remarks of Senator Long), and attributed the same position to the FTC and the Antitrust Division, 111 Conc. Rec. 8,432 (daily ed. April 28, 1965) (remarks of Representative Roosevelt), neither the drafters nor either of these agencies appear, during subsequent hearings, to huve considered the point as settled. In fact, one of the main foci of inquiry which the drafters suggested in recommending the bills to legislative committee was whether the then existing law could adequately deal with the problem. See Hearings Before the Subcomm. on Antitrust and Monopoly of the Senate Comm. on the Judiciary, Dual Distribution, 89th Cong., Ist Sess. 11 (1965). 
The NATURE OF The INQUiRY

Robinson-Patman proscribes price discrimination between different purchasers where the effect may be substantially to lessen competition. ${ }^{10}$ Whether the prohibition is available as a limitation on dual distribution depends initially upon whether the distributing division can be deemed a purchaser for purposes of the Act. ${ }^{20}$ While there have been isolated instances in which a court has disposed of the purchaser issue solely on the notions of sale and title passing, ${ }^{21}$ most

1015 U.S.C. $\$ 19$ (a), (d), (e) (1964). Section 2(a): "It shall be unlawful for any person engaged in commerce, in the course of such commerce, either directly or indirectly, to discriminate in price between different purchasers.... where the effect of such discrimination may be substantially to lessen competition or tend to create a monopoly in any line of commerce, or to injure, destroy, or prevent competition with any person who either grants or knowingly receives the benefit of such discrimination, or with customers of either of them: Provided, That nothing herein contained shall prevent differentials which make only due allowance for differences in cost. . . . And provided further, that nothing herein contained shall prevent persons engaged in selling goods ... from selecting their own customers in bona fide transactions and not in restraint of trade. Section 2(d): "It shall be unlawful for any person engaged in commerce to pay or contract for the payment of anything of value to or for the benefit of a customer of such person in the course of such commerce as compensation or in consideration for any services or facilities furnished by or through such customer . . . unless such payment or consideration is available on proportionately equal terms to all other customers competing in distribution of such products or commodities." Section 2 (e): "It shall be unlawful for any person to discriminate in favor of one purchaser against another purchaser . . . by contracting to furnish or furnishing, or by contributing to the furnishing of, any services or facilities ... upon terms not accorded to all purchasers on proportionately equal terms."

${ }^{20}$ See Shaw's, Inc. v. Wilson-Jones Co., 105 F.2d 331 (3d Cir. 1939); Reines Distribs., Inc. v. Admiral Corp., 256 F. Supp. 581 (S.D.N.X. 1966); Wholesale Auto Supply Co. v. Hickok Mfg. Co., 221 F. Supp. 935 (D.N.J. 1963); Sorrentino v. GlenGery Shale Brick Corp., 46 F. Supp. 709 (E.D. Pa., 1942).

One proposed Robinson-Patman amendment, S. 1842, 89th Cong., 1st Sess. (1965) ("A bill to amend the Clayton Act to prohibit vertically integrated companies from engaging in discriminatory practices against independent producers and distributors"), was intended to make the Act expressly applicable to vertically integrated enterprises to the same extent, id. $\$ 2 \mathrm{~A}$, and with the same limitations and defenses as were available under the Clayton Act to nonintegrated enterprises, id. $\$ 2 \mathrm{~A}$ (c) (3). This result was sought to be achieved through a declaration that the producer and the "related establishment," id., shall be deemed a seller and purchaser respectively, even though they are part of the same company. Moreover, the proscription would have applied to the actual extension of the discriminatory treatment by the producer as well as to the inducement of the receipt of the same. Id. $\$ 2 \mathrm{~A}(c)$. This portion of the bill does no more than declare that the provisions of the Act in its present form are applicable to cases involving dual distribution and as such adds nothing by way of more effective regulation.

${ }^{21}$ See Students Book Co. v. Washington Law Book Co., 232 F.2d 49 (D.C. Cir. 1955), cert. denied, 350 U.S. 988 (1956); Loren Specialty Mfg. Co. v. Clark Mfg. Co., 241 F. Supp. 493 (N.D. Ill. 1965), aff'd, 360 F.2d 913, cert. denied, 385 U.S. 957 (1966). 
courts have responded more perceptively, especially when a failure to find purchaser status would have rendered the Act impotent against a distribution technique susceptible of widespread use. Accordingly, when manufacturers have sold to nonfavored retailers through wholesalers, while selling directly to favored customers at lower prices, courts have relied on the manufacturer's control over the transaction between the wholesaler and the nonfavored retailer to conclude that the retailer was an indirect purchaser. ${ }^{22}$ Similarly, courts have indicated that the exercise of dominion and control by the manufacturer over the wholesaler, often a subsidiary of the manufacturer, is sufficient to constitute the manufacturer and the wholesaler a unitary seller, ${ }^{23}$ thus enabling the court to find competing purchasers on the retail level. In still other cases, courts have considered the independent wholesaler and the retailer a single unit for purposes of the Act, thus rendering the retailer a direct purchaser. ${ }^{24}$

${ }^{22}$ K.S. Corp. v. Chemstrand Corp., 198 F. Supp. 310, 312 (S.D.N.Y. 1961): "An indirect purchaser may come within section 2 when the manufacturer deals directly with him in promoting the sale of his product and exercises control over the terms on which he buys." Kraft-Phenix Cheese Corp., 25 F.T.C. 537, 546 (1937): "A retailer is nonetheless a purchaser though he buys indirectly if, as here, the manufacturer deals with him directly in promoting the sale of his products and exercises control over the terms upon which he buys." See Purolator Prods. v. FTC, 352 F.2d 874 (7th Cir. 1965); American News Co. v. FTC, 300 F.2d 104 (2d Cir.), cert. denied, 371 U.S. 824 (1962); Champion Spark Plug Co., 50 F.T.C. 30 (1953); Dentists' Supply Co., 37 F.T.C. 345 (1943); Luxor, Ltd., 31 F.T.C. 658 (1940); cf. Elizabeth Arden, Inc. v. FTC, 156 F.2d 132 (2d Cir. 1946), cert. denied, 331 U.S. 806 (1947).

"s See Klein v. Lionel Corp., 237 F.2d 13 (3d Cir. 1956); Baim \& Blank, Inc. v. Philco Corp., 148 F. Supp. 541 (E.D.N.Y. 1957). However, if the manufacturer sells directly only to favored customers, forcing others who wish to handle its products to deal through independent wholesalers at higher prices, the courts have been unable to afford relief. In Baim \& Blank, Inc. v. Philco Corp., supra, a case involving such a distribution arrangement, the court held that since the manufacturer lacked sufficient dominion and control over the subsidiary, the retailer who purchased from the subsidiary was not a purchaser from the manufacturer. Thus, there were not two purchasers from the same seller and no violation of the Act could be found. See also Massachusetts Brewers Ass'n v. P. Ballantine \& Sons, 129 F. Supp. 736 (D. Mass. 1955); Merck \& Co. v. Bronx Drug Co., 1963 Trade Cas. 78,794 (S.D.N.Y.). The courts may have been less anxious to broaden the scope of the Act in these cases in the belief that the refusal to deal is likely to be the result of concerted activity between the manufacturer and its subsidiary and therefore subject to $\$ 1$ of the Sherman Act. Moreover, it is unlikely that, absent concerted activity, the courts would be willing to make the manufacturer responsible for the pricing policies of independent wholesalers over which he exerts no control.

26 See Dayco Corp. v. FTC, 362 F.2d 180 (6th Cir. 1966) (jobbers create dummy wholesaler to obtain wholesale discount); Joseph A. Kaplan \& Sons v. FTC, 347 F.2d 785 (D.C. Cir. 1965) (retailer creates dummy subsidiary wholesaler to obtain wholesale discount); Monroe Auto Equip. Co. v. FTC, 347 F.2d 401 (7th Cir. 1965), cert. denied, 382 U.S. 1009 (1966); General Auto Supplies, Inc. v. FTC, 346 F.2d 311 (7th Cir.), cert. dismissed, 382 U.S. 923 (1965). 
This judicial consolidation is not without justification; for characteristically in these cases, a single retailer or jobber, or a group of them, has established a dummy wholesaler which buys from the manufacturer at the wholesale discount thereby allowing the participating retailers to undercut competitors. ${ }^{25}$

The above cases demonstrate that the courts have been most ingenious in their efforts to prevent circumvention of the RobinsonPatman Act through deviations in traditional business patterns, and further that considerations of a more functional nature actually determine what appears to be essentially a conceptual issue. In marked contrast to this approach is the only case which has considered the purchaser issue in a dual distribution context, though failing to recognize it as such. In Reines Distributors, Incorporated $v$. Admiral Corporation, ${ }^{26}$ Admiral invoiced merchandise to its Newark distributing branch at a price lower than that at which it sold to Reines, a franchised distributor of Admiral products competing with the Newark division in the New York metropolitan area. Unable to compete with the prices quoted by Newark, Reines brought suit under section 2 (a), (d), and (e) $)^{27}$ of the Robinson-Patman Act, alleging that Admiral discriminated in favor of Newark in the prices charged and in the services rendered. The branch was initially operated as a division of Admiral and was eventually incorporated as a wholly owned subsidiary for tax purposes, but it was later reinstated as a division when the tax advantage dissolved.28

Prior to hearing the substance of the claim, the district court in a preliminary decision passed favorably on Reines' petition to have the purchaser issue considered separately. ${ }^{29}$ On reaching the purchaser issue the court, reasoning that the substance rather than the form of the intracorporate relationship should govern, ${ }^{30}$ found that

\footnotetext{
${ }^{25}$ Another facet of the purchaser issue is the requirement that the plaintiff must be an actual and not merely a potential purchaser. See Package Closure Corp. v. Sealright Co., 141 F.2d 972 (2d Cir. 1944) (prospective purchaser); Shaw's, Inc. v. Wilson-Jones Co., 105 F.2d 331 (3d Cir. 1939) (refusal to deal excluded); United States v. Borden Co., 111 F. Supp. 562 (N.D. III. 1953), modified, 347 U.S. 514 (1954) (one sale insufficient). However, the rule has been subject to exception. See Aluminum Co. of America v. Tandet, 235 F. Supp. 11 (D. Conn. 1964) (no actual purchase necessary).

20256 F. Supp. 581 (S.D.N.Y. 1966).

${ }^{27}$ See note 19 supra for text of statute.

28256 F. Supp. at 585.

${ }^{29}$ Reines Distribs., Inc. v. Admiral Corp., 257 F. Supp. 619 (S.D.N.Y. 1965).

30256 F. Supp. at 585.
} 
"the operation of [the Newark branch] . . . was interlocked with the home office in Chicago to such a degree that Newark could not be deemed a separate entity." 31 This conclusion that Newark was not a purchaser as contemplated by the Act was premised upon several factors: Newark's managers were under the control of Admiral; Admiral's approval was requisite to Newark's extending credit to one of its customers; the division's books were regularly audited by agents of Admiral; Newark's bank account was controlled by Admiral; Newark's employees were paid by Admiral; Newark was not permitted to dump goods on the market for quick sale; and except in certain circumstances, Newark was unable either to reject the merchandise sent to it by Admiral or to set prices. ${ }^{32}$

This separate entity test, which is apparently based on notions of dominion and control, ${ }^{33}$ clearly does no more than describe the essential nature of the corporate division, and thereby effectively excludes from the scope of the Act the vertically integrated firm engaged in dual distribution. ${ }^{34}$ By mechanically employing a test generated by functional considerations in a distinguishable context, the court overlooked the basis upon which the decision should be made. The considerations underlying the decision are more properly whether the failure to find purchaser status will exempt from regulation a distribution technique susceptible of widespread use, and. whether such a technique may be utilized to produce the anticompetitive effects which the Act was intended to prevent. ${ }^{35}$ Since the wide-

s1 Id. at 584 .

${ }^{83} I d$.

s3 Id. at 585 .

sc "The sections involved herein of the Robinson-Patman Act when considered in relation to injury to competitors of a favored buyer (the so-called secondary line competition case) seem directed at discrimination by a seller caused by the size and strength of an independent buyer." Id. at 584. It is interesting to note, however, that the court did not stumble on the most obvious conceptual difficulty, namely, that it is not possible for someone to sell to himself. See Adelman, Integration and Antitrust Policy, 63 Harv. L. REv. 27, 51 (1949): "The stubborn fact that nobody can charge himself anything is too simple to be impressive." See also Comment, 53 Nw. U.L. REv. 253, 256 (1958).

${ }^{35}$ The court in Reines seems to have believed that the applicability of RobinsonPatman to the dual distribution technique could be determined independently of the overall antitrust policies reflected in the Sherman Act: "While this position seems logical in Sherman Act cases, the focus here is on the purposes of Robinson-Patman and the substance of the relevant transactions in this case in relation to those purposes." 256 F. Supp. at 583. It is well established, however, that the Act should be interpreted to coincide with and effectuate the Sherman Act. Automatic Canteen Co. of America v. FTC, 346 U.S. 61, 74 (1953): "[I]t is our duty to reconcile [RobinsonPatman] ... with the broader antitrust policies that have been laid down by Con- 
spread use of the dual distribution technique would seem apparent, ${ }^{36}$ the primary consideration in determining the applicability of Robinson-Patman becomes whether dual distribution is capable of producing those discriminatory acts sought to be proscribed by it.

\section{The Theoretical Basis: Price Discrimination and ANTICOMPETITIVE EFFECTS}

Section 2 (a) of the $\mathrm{Act}^{37}$ proscribes price discrimination ${ }^{38}$ by one

gress."; FTC v. Motion Picture Advertising Serv. Co., 344 U.S. 392, 406 (1953) (Frankfurter, J., dissenting): "It is also incumbent upon us to seek to rationalize the four statutes toward a common end and make of them, to the extent that what Congress has written permits, a harmonious body of law." See also United States v. Standard Oil Co., 337 U.S. 293, $297-98$ (1949); Standard Fashion Co. v. Magrane-Houston Co., 258 U.S. 346, 355 (1922). Some courts, however, have recognized the difficulty of such an endeavor. See FTC v. Motion Picture Advertising Serv. Co., supra (Frankfurter, J., dissenting); FTC v. Rubberoid Co., 343 U.S. 470, 483 (1952) (Jackson, J., dissenting); Standard Oil Co. v. FTC, 340 U.S. 231, 249 (195I). Nevertheless, the Clayton Act and its Robinson-Patman amendment have traditionally been considered as functional auxilliaries of the Sherman Act. See United States v. Philadelphia Nat'l Bank, 374 U.S. 321, 355 (1963) ( $\$ 7$ Clayton Act); United States v. E.I. duPont deNemours \& Co., 353 U.S. 586, 597 (1957) (same); Standard Oil Co. v. FTC, supra at 249 (Robinson-Patman); United States v. National City Lines, Inc., 334 U.S. 573, 580-87 (1948) (\$ 12 Clayton Act); Standard Fashion Co. v. MagraneHouston Co., supra at 355 (\$3 Clayton Act); Continental Baking Co. v. Utah Pie Co., 349 F.2d 122, 149 \& n.28 (10th Cir. 1965), rev'd on other grounds, 386 U.S. 685 (1967) (Robinson-Patman); Karseal Corp. v. Richfield Oil Corp., 221 F.2d 358, 365 (9th Cir. 1955) (same); Transamerica Corp. v. Board of Governors of Fed. Reserve Sys., 206 F.2d 163, 166 (3d Cir.), cert. denied, 346 U.S. 901 (1953) (\$7 Clayton Act); Balian Ice Cream 166 (3d Cir.), cert. denied, 346 U.S. 901 (1953) ( $\$ 7$ Clayton Act); Balian Ice Cream Co. v. Arden Farms Co., 94 F. Supp. 796, 800 (S.D. Cal. 1950), aff'd, 231 F.2d 356 (9th Cir. 1955), cert. denied, 350 U.S. 991 (1956) (Robinson-Patman).

See Purolator Prod., Inc. v. FTC, 352 F.2d 874 (7th Cir. 1965), in which the court considered price discrimination and anticompetitive effects before deciding the purchaser issue.

${ }^{36}$ See note 6 supra.

${ }^{87}$ For text of the Robinson-Patman Act see note 19 supra.

${ }^{38}$ The courts have consistently refused to find price discrimination where the same price is charged and no other discriminatory tactics are present. See FTC v. Anheuser-Busch Corp., 363 U.S. 536 (1960); Krug v. International Tel. \& Tel. Corp., 142 F. Supp. 230 (D.N.J. 1956); Klein v. Lionel, 138 F. Supp. 560 (D. Del.), aff'd, 237 F.2d 13 ( $3 \mathrm{~d}$ Cir. 1956). Some courts have even gone so far as to say that where some consumers are charged less than a retailer, there is no price discrimination if the retailer could not have competed even if the same price were to be charged, see Secatore's, Inc. v. Esso Standard Oil Co., 171 F. Supp. 665 (D. Mass. 1959), though it is recognized that charging the same price does not always foreclose one's ability to compete in these cases, see Sano Petroleum Corp. v. American Oil Co., 187 F. Supp. 345, 355 (E.D.N.Y. 1960). A growing number of cases, however, have found price discrimination where the same price was charged but "indirect" discriminatory tactics were employed. See notes $45-49$ infra and accompanying text.

It should also be noted that a different result may be obtained depending upon whether the activity amounts to an indirect price discrimination, which falls under $\$ 2$ (a), or discriminatory payments or services and facilities, which falls under $\S \S 2$ (d) and (e). Under the former, cost justification and good faith meeting of competition 
seller between two or or more purchasers if such discrimination may $^{38}$ substantially lessen competition ${ }^{40}$ on any of three competitive

defenses are available while under the latter they are not. Another distinguishing feature appears to be whether the discrimination takes place in the original sale or is involved in subsequent resale by the purchaser; the former is controlled by $\$ 2$ (a) and the latter by $\$ \S 2$ (d) and (e). See General Foods Corp., 52 F.T.C. 798, 814-15, 828 (1956); Carpel Frosted Foods, Inc., 48 F.T.C. 581, 602 (1951); New England Confectionery Co., 46 F.T.C. 1041, 1059-60 (1949). See generally D. BAUM, supra note 8, at 21-22; C. EDWArDs, The Price Discrimination Law 286.348 (1959); W. Patman, Complete Guide to the Robinson-Patman Act 11-101 (1963); F. Rowe, Price Discrimination Under the RobINSON-PATMAN ACT 87-107 (1962).

Functional discounts, a "traditional pricing technique by which sellers compensated buyers for expenses incurred by the latter in assuming certain distributive functions [and] .... provided for graduated discounts to customers classified in accordance with their place in the distribution chain, namely, wholesaler, retailer and consumer in diminishing amounts," Doubleday \& Co., 52 F.T.C. 169, 207 (1955), are, however, recognized as permissible under the Act. "Inasmuch as traditional discounts of this type, as any other price differentials, remained lawful under the Robinson-Patman Act unless engendering adverse effects on competition, the ordinary discounts to wholesalers and retailers were considered entirely legal." Id.

However, Congress as well as the courts has refused to require functional discounts, even in those cases where the same price charged to functionally distinct purchasers results in reduced competitiveness on the part of one of the purchasers. Proposed amendments to the definition of price discrimination sought to compel price adjustments in these situations. H.R. 10304, 85th Cong., 2d Sess. (1958); H.R. 10305, 85th Cong., 2d Sess. (1958); H.R. 10640, 85th Cong., 2d Sess. (1958); H.R. 10999, 85th Cong., 2d Sess. (1958); H.R. 11409, 85th Cong., 2d Sess. (1958). The proposed bill was criticized by the Antitrust Division of the Justice Department on two grounds: (1) the provision forced the seller to control the price relationships of independent distributors-a result which is contrary to antitrust objectives. See Hearings Before the Antitrust Subcomm. of the House Comm. of the Judiciary, Functional Discounts, 85th Cong., 2d Sess. 50.51 * (1958); (2) such a rule could easily be circumvented by the establishment of a jobber between the manufacturer and the wholesaler. Id.

${ }^{80} 15$ U.S.C. $\$ 2$ (a) (1964). See note 19 supra. Failure to allege lessened competition or a tendency to lessen competition will cause dismissal of the action. See Hill v. Linton, 1950-51 Trade Cas. 63,991 (N.D. Ill. 1950). Early cases evidenced a disagreement among the courts as to whether the test for potential competitive injury is a "reasonable possibility" or a "reasonable probability." Compare Corn Prod. Ref. Co. v. FTC, 324 U.S. 726, 738, 742 (1945), with FTC v. Morton Salt Co., 334 U.S. 37, 55-56 (1948) (Jackson, J., dissenting in part). Courts have since tended toward the "reasonable probability" test. See Standard Motor Prod., Inc. v. FTC, 265 F.2d 674, 676 (2d Cir.), cert. denied, 361 U.S. 827 (1959); Moog Indus., Inc. v. FTC, 238 F.2d 43, 51 (8th Cir. 1956), aff'd, 355 U.S. 411 (1958) (per curiam); National Lead Co. v. FTC, 227 F.2d 825, 835 (7th Cir. 1955), rev'd on other grounds, 352 U.S. 419 (1957). Two cases applied both without deciding which one was correct. Monroe Auto Equip. Co. v. FTC, 347 F.2d 401, 404 (7th Cir. 1965), cert. denied, 382 U.S. 1009 (1966); E. Edelmann \& Co. v. FTC, 239 F.2d 152, 154 (1956), cert. denied, 355 U.S. 941 (1958). Some courts still adhere to the "reasonable possibility" test. See Atlas Bldg. Prods. Co. v. Diamond Block \& Gravel Co., 269 F.2d 950, 957 (10th Cir. 1959), cert. denied, 363 U.S. 843 (1960). It would seem that, practically, the distinction is merely semantic since what may satisfy the "reasonable possibility" test in one case may well satisfy the "reasonable probability" test in another.

Testimony of lack of actual effect on competition is not conclusive. See E. Edelmann \& Co. v. FTC, supra at 155; Tri-Valley Packing Ass'n v. FTC, 329 F.2d 694, 708 (9th Cir. 1964). But see American Oil Co. v. FTC, 325 F.2d 101, 104 (7th Cir.), cert. denied, 
377 U.S. 954 (1963); FTC v. Anheuser-Busch, Inc., 289 F.2d 835, 843 (ith Cir. 1961). These cases have been criticized as "changing the statutory standard" because they "may be galvanized into a weapon by those who would limit the thrust of the Robinson-Patman Act." D. BAuM, supra note 8, at 19-20.

It is well settled, however, that the statutory language does not encompass a "mere possibility" even in those jurisdictions which accept the "reasonable possibility" test. See Corn Prod. Ref. Co. v. FTC, supra; Monroe Auto Equip. Co. v. FTC, supra; E. Edelmann \& Co. v. FTC, supra. Similarly, a de minimus rule is also present which prevents application of the Act in those cases where the anticompetitive effect is "temporary" or "minimal." See Continental Baking Co. v. Utah Pie Co., 349 F.2d 122, 150 (10th Cir. 1965), rev'd on other grounds, 386 U.S. 685 (1967); American Oil Co. v. FTC, supra at 105-06 (gasoline price war); Minneapolis Honeywell Regulator Co. v. FTC, 191 F.2d 786, 792 (7th Cir. 1951), cert. dismissed, 344 U.S. 206 (1952); Borden Co. v. FTC, 339 F.2d 953, 957 (7th Cir. 1964); Hill v. Linton, supra. See also Albert $\mathrm{H}$. Cayne Equip. Corp. v. Union Asbestos Rubber Co., 220 F. Supp. 784, 788-89 (S.D.N.Y. 1963).

Predatory intent is neither determinative nor necessary, but it is relevant in determining whether a given discrimination may substantially lessen competition. See Balian Ice Cream Co. v. Arden Farms Co., 231 F.2d 356, 369 (9th Cir. 1955), cert. denied, 350 U.S. 991 (1956): "[I]ntent is not an essential factor to a $\$ 2$ (a) violation, although, if the intent ... . were found to exist, it might tend to render the injury probable."; see H. J. Heinz Co. v. Beech-Nut Life Savers, Inc., 181 F. Supp. 452, 465 (S.D.N.Y. 1960). It should be noted that in primary line cases predatory intent has been a substantial consideration in finding a $\$ 2$ (a) violation. See Moore v. Mead's Fine Bread Co., 348 U.S. 115, 116-17 (1954); Atlas Bldg. Prods. Co. v. Diamond Block \& Gravel Co., supra at 956; Maryland Baking Co. v. FTC, 243 F.2d 716 (5th Cir. 1957): One court has intimated that predatory intent was a prerequisite for $\$ 2$ (a) primary line violations. Anheuser-Busch, Inc. v. FTC, supra at 842-43. A recent FTC decision, however, found a $\$ 2$ (a) violation where intent was lacking: "[T]he test for finding competitive injury on the primary, or seller's level, in the absence of predatory intent, is whether the evidence shows significant diversion of business from the discriminator's competitors to the discriminator or diminishing profits to competitors resulting either from the diversion of business or from the necessity of meeting the discriminator's lower prices, provided that these immediate actual effects portend either a financial crippling of those competitors, a possibility of an anticompetitive concentration of. business in larger sellers, or a significant reduction of the number of sellers in the see H.J. Heinz Co. v. Beech-Nut Life Savers, Inc., 181 F. Supp. 452, 465 (S.D.N.Y. (emphasis added). See generally F. RowE, supra note 38 , at $144-50$.

to There has been substantial controversy over whether the mere injury to a single competitor is sufficient to establish a $\$ 2$ violation. Although statements in the congressional reports concerning the Act would arguably indicate that the Act proscribes all injuries to competition, see S. REP. No. 1502, 74th Cong., 2d Sess. 3-4 (1936); H.R. REP. No. 2287, 74th Cong., 2d Sess. 7-9 (1936), the courts have not seen fit to give it such a broad interpretation: "The protection intended to be afforded by the statute is directed to the preservation of competition. The statute's concern with the individual competitor is but incidental," American Oil Co. v. FTC, 325 F.2d 101, 104 (7th Cir. 1963), cert. denied, 377 U.S. 954 (1964) (emphasis added). "The Act is really referring to the effect upon competition not merely upon competitors .... In this respect $\$ 2$ (a) must be read in conformity with the public policy of preserving competition, but it is not concerned with mere shifts of business between competitors. It is concerned with substantial impairment of the vigor or health of the contest for business, regardless of which competitor wins or loses." Anheuser-Busch, Inc. v. FTC, 289 F.2d 835, 840 (7th Cir. 1961); accord, Atlas Bldg. Prods. Co. v. Diamond Block \& Gravel Co., 269 F.2d 950, 954 (10th Cir. 1959), cert. denied, 363 U.S. 843 (1960); see Balian Ice Cream Co. v. Arden Farms Co., 104 F. Supp. 796, 801 (S.D. Cal. 1952), aff'd, 231 F.2d 356 (9th Cir. 1955), cert. denied, 350 U.S. 991 (1956). 
levels. ${ }^{41}$ The language of the statute, ${ }^{42}$ its structure, ${ }^{48}$ and the myriad types of practices found to be discriminatory thereunder ${ }^{44}$ indicate a legislative intent and a determined judicial effort not to allow the Act to be circumvented by manipulation of the large number of factors present in the complex market relationships which exist today. Consequently, the courts have found many practices which are not in themselves price discriminations to be sufficiently equivalent to justify application of the statutory prohibition. Hence where manufacturers have charged the same price to competing purchasers while at the same time favoring one of them with such extra benefits as

In a given case, however, injury to a competitor may indeed reflect a potential injury to competition. See H.J. Heinz Co. v. Beech-Nut Life Savers, Inc., 181 F. Supp. 452, 463-64 (S.D.N.Y. 1960). See also Atlas Bldg. Prods. Co. v. Diamond Block \& Gravel Co., supre at 954. However, the cases which assert the injury-to-competition test are those in which the discriminaiton was found not to be actionable; whereas those cases finding $\$ 2$ violations do not inquire beyond injury to the competitor. This approach perhaps reveals a belief that injury to a competitor is in all but extreme cases a true indicator of reasonably probable injury to competition. It may be, however, that the courts are unwilling to complicate the Robinson-Patman Act with the complex considerations presented when the actual effect on competition is the issue under the Sherman Act. This reluctance may tend to make reconciliation of the two acts considerably more difficult.

1 Sections 2 (d) and (e), 15 U.S.C. $\$ \S 13$ (d), (e) (1964), do not permit the defenses present in $\$ 2(a)$, namely cost justification and good faith meeting of competition. It has been argued that the purpose behind the distinction was to force sellers to confine their discriminations to price differentials which can more readily be detected, thereby making the cost defense capable of more accurate evaluation. See D. BAvM, supra note 8 , at 50 . The general philosophy behind $\$ \S 2$ (d) and (e) was to remove any loopholes through which the seller could effect a discrimination which the Act might not otherwise reach. See H.R. REP. No. 2287, 74th Cong., 2d Sess. 15-16 (1936). See also H.R. Rep. No. 2951, 74th Cong., 2d Sess. (1936) (conference report). The courts have followed this interpretation. "The purpose of the section here involved was to eliminate all discrimination under the guise of payments for advertising or promotional services and Congress employed language that would cover any evasive methods." $P$. Lorillard Co. v. FTC, 267 F.2d 439, 443 (3d Cir.), cert. denied, 361 U.S. 928 (1959). For an exhaustive treatment of the restrictions on some forms of indirect favoritism, see G. FELD. man \& B. Zorn, The Robinson-Patman Act: Advertising and Promotional Allowances (1948).

12 ". . . where the effect of such discrimination may be substantially to lessen competition or tend to create a monopoly in any line of commerce, or to injure, destroy, or prevent competition with any person who either grants or knowingly receives the benefit of such discrimination, or with customers of either of them." 15 U.S.C. \$13 (a) (1964). Thus, there are three levels of competition protected by the Act: primary line competition between sellers or, in Robinson-Patman cases, between the discriminator and his competitors; secondary line competition between the buyer who is the target of the discrimination and his competitors; tertiary line competition between customers of the buyer.

18 The statute proseribes both direct and indirect discriminations. See 15 U.S.C. $\S 13$ (a) (1964).

"See note 38 supra. 
freight allowances, ${ }^{45}$ interest free loans, ${ }^{48}$ free samples and cumulative quantity discounts, ${ }^{47}$ or purchase options, ${ }^{48}$ the courts have consistently applied the Act, ${ }^{48}$ apparently on the theory that such tactics result in lower costs to the favored purchaser.

This tendency to look to the practical effect of the manufacturer's marketing techniques has prevailed in the search for potential anticompetitive effects on all three competitive levels. Original section 2 of the Clayton Act, ${ }^{50}$ which was amended by Robinson-Patman, was designed to prevent geographic price cutting which effected primary line competition. ${ }^{51}$ Typically, the manufacturer would lower the price of its product in an area of sharp competition below that which local competitors could effectively meet. The price cut would then be supported by higher prices charged in areas where competition was slight or nonexistent. ${ }^{52}$ With the passage of the RobinsonPatman Act, however, this tactic became just one of the several forms of prohibited price discrimination. ${ }^{53}$ Although to the present time

\footnotetext{
¿s See, e.g., Sano Petroleum Corp. v. American Oil Co., 187 F. Supp. 345 (E.D.N.Y. $1960)$.

'B See, e.g., United States v. Borden Co., 1952-53 Trade Cas. 68,230 (N.D. Ill. 1953) (consent decree).

17 See, e.g., National Nut Co. v. Kelling Nut Co., 61 F. Supp. 76 (N.D. Ill. 1945).

ts See, e.g., Corn Prods. Ref. Co. v. FTC, 324 U.S. 726 (1945).

40 Other examples of nonprice favoritism included coupois redeemable for cash, see, e.g., Idaho Canning Co., 58 F.T.C. 657 (1961), and extended terms for procurement of trade discounts, see, e.g., National Grain Yeast Corp., 33 F.T.C. 684 (1941). Sce note 38 supra.

so 38 Stat. 730 (1914), as amended, 15 U.S.C. $\$ 13$ (1964).

${ }^{81}$ See FTC v. Anheuser-Busch, Inc., 363 U.S. 536, 542-45 (1960).

62 Id. at 540-41.

${ }^{58}$ See id. at 543-45. Prior to consideration of the Anhetuser-Busch price cutting case, it was requisite under the Robinson-Patman Act that the purchasers involved be competitors. See Chicago Sugar Co. v. American Sugar Ref. Co., 176 F.2d 1, 10 (7th Cir. 1949), cert. denied, 338 U.S. 948 (1950). This rule made application of the Act to price cutting difficult, since such cases did not typically involve competing purchasers. In the face of this dilemma the courts opted to avoid exempting this anticompetitive pricing tactic and excepted the required competition in these cases. FTC v. Anheuser-Busch, Inc., 363 U.S. 536, 543-44 (1960): "It is, of course, quite true . . that the 1936 Robinson-Patman amendments to the Clayton Act were motivated principally by congressional concern over the impact upon secondary-line competition of the burgeoning mammoth purchasers, notably chain stores. However, the legislative history of these amendments leaves no doubt that Congress was intent upon strengthening the Clayton Act provisions, not weakening them, and that it was no part of Congress' purpose to curtail the pre-existing applicability of $\$ 2$ (a) to price discriminations affecting primaryline competition." Moore v. Mead's Fine Bread Co., 348 U.S. 115 (1954); Atlas Bldg. Prods. Co. v. Diamond Block \& Gravel Co., 269 F.2d 950, 954 (10th Cir. 1959), cert. denied, 363 U.S. 843 (1960); Maryland Baking Co. v. FTC, 243 F.2d 716 (5th Cir. 1957). This result again demonstrates the flexibility with which the courts have approached
} 
this geographic price cutting has been the only context in which the courts have considered primary level anticompetitive effects, this application does serve to demonstrate that such an inquiry is possible under the Act.

Though the main legislative concern in the enactment of Robinson-Patman was with the plight of the small seller generally, ${ }^{54}$ the most immediate impact of the discrimination inherent in dual distribution is in many cases on the independent wholesaler. Consequently the search for anticompetitive effects is frequently on the secondary level. The most typical form of favoritism on this level is the same as that found on the tertiary level: discounts to quantity purchasers. When lower prices are offered to large wholesalers, a Robinson-Patman violation will result unless the variance reflects an actual cost difference..$^{55}$

Traditional tertiary level cases have involved the use of coercive buying power by large chain stores. ${ }^{58}$ Typically, a large chain store forced discriminatory price and service concessions by threatening to cease purchasing from the supplier. "The small competing retailer who was unable to exert similar pressure was forced to pay the higher price. A realization that the original section 2 of the Clayton Act could not cope with this problem, ${ }^{57}$ coupled with the scope of the abuse revealed by the Chain Store Investigation, ${ }^{58}$ provided the primary impetus for enactment of the Robinson-Patman Amendment.

While the courts generally need not seek potential competitive injury beyond the level at which the discrimination is effected, they will consider the effect upon other levels when necessary. Hence in price cutting cases, where the discrimination takes place on the secondary level, judges may look to the primary level for anti-

cases where the issue has been the applicability of the Act to a particular distribution technique.

os See W. Patman, supra note 38, at 7-10.

${ }^{\mathrm{s}}$ See, e.g., FTC v. Morton Salt Co., 334 U.S. 37 (1948).

so See W. PATMAN, supra note 38, at 54, 126-29. Chain store purchasers would not appear to represent the purest form of tertiary competitor, since they often purchase directly from producers, thereby competing with wholesalers for advantageous delivery schedules and other services.

${ }^{57}$ The permissibility of unlimited quantity discounts and the then current form of the good-faith-meeting-of-competition defense presented easy avenues for circumvention of the Clayton Act proscriptions. See C. Edwards, supra note 38, at 5-12.

${ }^{58}$ The federal Trade Commission, Final Report on the Chain Store Investication, S. Doc. No. 4, 74th Cong., lst Sess. (1934). 
competitive effects. ${ }^{59}$ Similarly, in other secondary level discrimination cases relief may be granted to a wholesaler even though the alleged injury occurred at the retail level. In Krug $v$. International Telephone is Telegraph Corporation, ${ }^{60}$ a wholesaler instituted a Robinson-Patman action alleging competitive injury to his customers because the manufacturer was selling directly to retailers at prices lower than those charged to the plaintiff wholesaler, whose customers competed with the favored retailers. The district court held that "it would seem to make no difference that [the wholesaler's] injury was not suffered by his inability to compete with others on his own distributive level but by the failure of his customers to meet the competition of another immediate purchaser from the manufacturer."61 The Krug case is merely indicative of the responsiveness to business realities which the courts have reflected toward both the inquiry as to potential anticompetitive effects and to the price discrimination issue. Conceivably the courts would be equally receptive to proof that a novel distributive technique such as dual distribution may be capable of producing the same results.

A firm engaged in dual distribution is clearly capable of price discrimination in its conventional forms. The manufacturer may discriminate between two independent purchasers at a marketing level other than that at which it undertakes dual distribution. Moreover, even on the level where it is engaged in favored distribution to its own division, a manufacturer can discriminate between independent purchasers. The present inquiry is not, however, whether price discrimination can be found concurrently with dual distribution, but rather whether this marketing technique can produce such discrimination. Consequently, the focus of the inquiry is more properly whether the techniques employed by manufacturers in favoring their division distributor over independent customer-competitors constitute price discrimination as it is conceived by the courts in other contexts.

One of the most obvious discriminatory techniques available to the firm practicing dual distribution is cost allocation among the various levels of production and distribution. While the effect of

${ }^{59}$ Cf. FTC v. Anheuser-Busch Co., 363 U.S. 536, 542-44 (1960); E.B. Muller v. FTC, 142 F.2d 511 (6th Cir. 1944).

${ }^{00} 142$ F. Supp. 230 (D.N.J. 1956).

${ }^{01} \mathrm{Id}$. at 236. 
such allocation on the overall profit of an integrated enterprise is slight, its effect on independent customer competitors may be devastating. An important precedent in an analogous area is provided by United States $v$. Aluminum Company of America. ${ }^{62}$ Alcoa, which controlled over ninety percent of the virgin aluminum ingot market in the United States, ${ }^{63}$ was also a fabricator of aluminum sheet in competition with independent fabricators who purchased its aluminum ingot. Since the price it charged the integrated fabricators was not the real determinant of the overall profit realized from the finished product, Alcoa allocated most of its costs, including part of the fabrication costs, to the price of ingot. By this device Alcoa raised the cost of ingot to a point at which the independent sheet rollers who bought the ingot "could not pay the expenses of 'rolling' the 'sheet' and make a living profit out of the price at which 'Alcoa' itself sold 'sheet.' "64 The only difference between Alcoa and dual distribution situations is that in the latter the purchasers are wholesalers and retailers rather than fabricators. Consequently, a manufacturer can favor its division distributor by allocating part of the cost of distribution to the primary level. Although both the division and the independent are "charged" the same price, the independent distributor is made to absorb costs not fairly allocable to the product he receives.

If Robinson-Patman were only interpreted to require a price difference this discriminatory treatment would be effectively exempted from proscription until it actually achieved monopoly proportions. However, the courts, as has been noted, ${ }^{65}$ have gone beyond mere price difference to find Robinson-Patman violations where,

\footnotetext{
os 148 F.2d 416 (2d Cir. 1945).

os Id. at 425 .

ot Id. at 437. The Alcoa scheme can be illustrated thusly: if the selling price of sheet aluminum is $\$ 10.00$ per 100 feet, the cost of the ingot necessary to produce one hundred feet of sheet $\$ 5.00$, and the cost of fabrication $\$ 4.00$, with a profit of $\$ 1.00$, Alcoa could raise the cost of ingot to $\$ 5.75, \$ .75$ of which is transferred from the cost of fabrication, and still sell the sheet aluminum for $\$ 10.00$ with a $\$ 1.00$ profit. However, the independent fabricator who is forced to pay the extra $\$ .75$ for the ingot, in order to compete with Alcoa, must reduce his profit to $\$ .25$ per 100 feet. If Alcoa raised the cost of ingot to or above $\$ 6.00$, the independent fabricator would realize no profit. Thus, though cost allocation is of little significance to the integrated firm, it is of vital importance to its customer-competitors. Where these activities have the intent or effect of monopolization, they may be prosecuted under $\$ 2$ of the Sherman Act. Id. at 438.

${ }^{\circ}$ See notes $45-49$ supra and accompanying text.
} 
despite price similarity, some other discriminatory tactic yields lower costs for the favored purchaser. Comparable analysis would demand an identification of discrimination in the dual distribution context when the same price is charged, but cost allocation is used to undercut the independent wholesaler. The only difference between these two situations is in form: in the usual case the discrimination results in lower costs to the favored purchaser, whereas in the dual distribution case it results in higher actual costs to the nonfavored purchaser.

It is, of course, difficult to draw a perfect analogy from cases where the manufacturer discriminates in favor of one independent distributor over another, employing such tactics as purchase options ${ }^{66}$ and free samples, ${ }^{67}$ to cases in which the manufacturer favors an owned and controlled division, using the device of cost manipulation. However, the difficulty arises only from the difference in the form of the intercorporate and intracorporate relationships involved and not from the substance of the practices employed. ${ }^{68}$ Consequently, the courts would be in harmony with present case law if they were to find an indirect price discrimination by the manufacturer in this context.

Even if dual distribution is shown to produce price favoritism, there can be no remedy unless that discrimination may have the potential anticompetitive effects sought to be prevented by the Act. ${ }^{69}$ Significantly, the adverse effects of such discrimination can be observed on all three levels of competition. On the secondary level.

\footnotetext{
${ }^{\circ 0}$ See Corn Prods. Ref. Co. v. FTC, 324 U.S. 726, 739-42 (1945).

"r See National Nut Co. v. Kelling Nut Co., 61 F. Supp. 76 (N.D. I1l. 1945).

${ }^{\circ 8}$ Another proposed amendment, S. 1844, 89th Cong., Ist Sess. (1965), "A bill to amend the Clayton Act to prohibit vertically integrated companies from engaging in anticompetitive pricing practices," was intended to proscribe one of the injurious activities made possible by dual distribution, namely, the "price squeeze." In this situation, the integrated firm allocates an artificial percentage of cost and profit to the level upon which the independent customer competes, thus leaving him little or no profit margin at that level. See Hearings Before the Subcomm. on Antitrust and Monopoly of the Senate Comm. on the Judiciary, Dual Distribution, 89th Cong., 1st Sess. 11-12, 100 (1965). The bill required that "adequate and fair differentials" must be maintained between the prices charged upon those levels at which the integrated enterprise competes with independent competitors. S. 1844, 89th Cong., lst Sess. §2A (1965). Such a scheme is dangerously analogous to requiring functional discountsa measure which both the courts and Congress have evidenced great reluctance to embrace since such techniques tend to freeze prices, a result which in itself is anticompetitive. See note 41 supra. In addition to the possible anticompetitive results, the provision strikes at the effect-artificial cost allocation to one level of production or distribution-rather than the cause of the squeeze. Such allocation can arguably be described as an "indirect price discrimination" in appropriate cases, and thereby be subject to proscription under the present Robinson-Patman Act.

${ }^{60}$ See note 35 supra and accompanying text.
} 
these possible detriments are both immediate and readily apparent. ${ }^{70}$ Since the competitive cost of the product to the independent distributor is greater than that to the division, the independent will either be forced to sell to retailers at a higher price or to charge the same price but operate with a lower margin of profit. ${ }^{71}$ In the former situation inability to meet the division's price will reduce the independent's share of the market. Similarly, in the latter situation the lower margin of profit may reduce efficiency and thereby result in a loss of sales. Though these consequences may not inevitably occur in every instance where discrimination is employed, they do suggest that such effects are possible.

In those cases in which this indirect discrimination results in injury to the independent wholesaler, both existing and potential primary level competition may also be adversely affected..$^{72}$ Within most industries there are likely to be small, competing manufacturers which cannot integrate and must depend upon independent distributors for efficient, competitive distribution.73 Utilization of the dual distribution technique by an integrated firm to reduce the distributor's absolute profits or his profit margin can deprive the smaller producers of quality outlets. This result is especially likely in an industry where consumer preference for the integrated firm's product requires all wholesalers to handle it if they are to survive. ${ }^{74}$ The anamolous situation created by a failure to apply Robinson-Patman in these cases is plain. In order to remain competitive, the small competitor, unable to integrate by internal expansion, ${ }^{75}$ is forced to attempt integration by contract, ${ }^{78}$ but it thereby places itself under the full thrust of the Act. The integrated competitor, however, remains exempt.

70 See House Select Committee on Small Business, The Impact Upon Small Business of Dual Distribution and Related Vertical Integration, H.R. Rep. No. 1948, 88th Cong., 2d Sess. (1964).

71 See C. EDwaros, supta note 38, at 532.

"A A reduction of the independent wholesaler's volume of sales can adversely affect the distribution costs of competing manufacturers. Cf. Kessler \& Stern, Competition, Contract \& Vertical Integration, 69 YALE L.J. 1, 18 (1959).

7s See J. BAIN, Barriers to New Competition (1962); cf. FTC v. Procter \& Gamble Co., 386 U.S. 568 (1967); Brown Shoe Co. v. United States, 370 U.S. 294, 332-34 (1962).

74 See FTC v. Procter \& Gamble Co., 386 U.S. 568 (1967); United States v. Parke Davis 8: Co., 362 U.S. 29 (1960); House of Materials, Inc. v. Simplicity Pattern Co., 298 F.2d 867 (2d Cir. 1962).

${ }_{75}$ See note 5 supra.

Io Id. 
The adverse effect on the independent distributor may also injure potential competition by creating an absolute cost advantage for the integrated enterprise which, in turn, deters the entry of new producers into the market. ${ }^{77}$ To the extent that vertical integration and dual distribution may be used effectively to weaken existing independent distribution outlets, or eliminate them entirely, the potential competitor is faced with the prospect of developing its own outlets. The difficulty of raising the capital for such an undertaking might in itself be an effective barrier to entry. ${ }^{78}$ Moreover, because the manufacturer not only has to be a maker but a seller as well, the prospective producer who is unsure of the competitiveness of its product may be unwilling to undertake this additional distributive function. ${ }^{78}$

The anticompetitive effect which occurs on tertiary level competition may be observed in situations where the manufacturer, after discriminating against the independent wholesaler, allows its division to sell only to favored retailers. Nonfavored retailers, consequently, are forced to purchase from the independent wholesalers at higher prices, thereby depressing competition at the retail level..$^{80}$ Thus, dual distribution is capable of producing price discrimination with consequent anticompetitive effects on all three levels of competition. Moreover, the orientation of this practice ${ }^{81}$ and the probability of

${ }^{77}$ See Kessler \& Stern, supra note 72, at 18; J. BaIN, supra note 73, at 214-15. Market foreclosure has long been a source of concern in Sherman Act cases, see, e.g., United States v. Columbia Steel Corp., 334 U.S. 495, 528-29 (1948); United States v. Paramount Pictures, Inc., 334 U.S. 131 (1948); United States v. Swift \& Co., 286 U.S. 106 (1932); Standard Oil Co. v. United States, 221 U.S. 1 (1911), and \$7 Clayton Act cases, see FTC v. Procter \& Gamble Co., 386 U.S. 568 (1967); Brown Shoe Co. v. United States, 370 U.S. 294 (1962); United States v. E. I. duPont deNemours \& Co., 353 U.S. 586 (1957), involving vertically integrated enterprises.

${ }^{78} \mathrm{Cf}$. J. Miller, Unfair Competition 212 (1941).

${ }^{70}$ If the manufacturer chooses to deal with existing, inefficient distributors, it is faced with higher variable costs. See Kessler \& Stern, supra note 72, at 16, 18; cf. J. MILLER, supra note 78, at 212; Lockhart \& Sacks, The Relevance of Economic Factors in Determining Whether Exclusive Arrangements Violate Section 3 of the Clayton Act, 65 HARv. L. REv. 913, 922 (1952).

so In Krng v. International Tel. \& Tel. Co., 142 F. Supp. 230 (D.N.J. 1956), the manu. facturer was accused of selling directly to retailers at lower prices than those at which it sold to the plaintiff wholesaler whose customers were in competition with the favored retailers. The court found that, even where there is no present or potential effect on the wholesaler's ability to compete on his own level, the Act has been violated where such discriminations might affect the ability of his customers to compete. Id. at $235-36$.

81 In contrast to the majority of traditional Robinson-Patman cases, the discrimination in dual distribution is stimulated by the interests of the discriminator and not in- 
defensive integration render these effects, when realized, considerably more devastating. These factors furnish further justification for bringing this distribution technique within the purview of the Act.

\section{IMPEDIMENTS to EFFECTIVE REgULATION}

Two significant impediments to the effective application of Robinson-Patman are the difficulty of exposing discriminatory activity by the integrated enterprise and the possibility of retaliatory refusals to deal. The extent to which a firm is integrated will determine its ability to manipulate costs among the various levels of production and distribution. Since the more integrated firm has a smaller proportion of separable costs relative to total costs, it can more easily disgnise discriminatory cost allocation, thus rendering effective exposure more difficult.82 This problem has been recognized in Congress in the form of a proposed amendment to Robinson-Patman which would require all ownership integrated firms to file separate profit and loss statements for company owned plants and distribution outlets participating in dual distribution. ${ }^{83}$ This requirement would

duced by the buying power of a third party. However, since the focus of the Act is upon the existence of discriminatory practices and their anticompetitive effects, see Krug v. International Tel. \& Tel. Co., 142 F. Supp. 230, 236 (D.N.J. 1956), and not the purpose or tent with which they were initiated, see Balian Ice Cream Co. V. Arden Farms Co., 231 F.2d 356, 369 (9th Cir. 1955), cert. denied, 350 U.S. 991 (1956); H. J. Heinz Co. v. Beech-Nut Life Savers, Inc., 181 F. Supp. 452, 465 (S.D.N.Y. 1960), the distinction is of limited significance.

${ }^{82}$ See Adelman, Integration and Antitrust Policy, 63 HARv. L. REv. 27, 30 (1949), quoting National Bureau of Economic Research, Commiltee on Price Discriminamon, Cost Behavior and Price Policy 174 (1943). See also Comment, 53 Nw. U.L. REV. 253 (1958).

Bs The amendment, "A bill to require certain companies engaged in dual distribution to disclose separate annual operating data on each of their establishments which competes with independent customers of such companies in the sale and industrial use of these products ..." , S. 1843, 89th Cong., Ist Sess. (1965), recognized one of the most difficult problems appendant to effective regulation of dual distribution under the Act, namely, the gathering of evidence sufficient to show that within a highly com. plex and sophisticated intracorporate relationship there exists discriminatory activities injurious to independent customer-competitors. Section 3 (a) of the proposed amendment provides that each firm employing dual distribution shall publish annually fignres reflecting the aggregate dollar amount of its net sales to independent customers and the dollar amounts or value of net sales or transfers to individual related establishments. Section 4 provides that the enterprise employing dual distribution must also publish a "separate annual operating statement" for each of its related establishments which is a party to dual distribution. Such statement shall contain "at least" total annual net sales; cost of goods sold, including cost of products purchased from related and nonrelated establishments; operating overhead; and net profit and loss from operations. Moreover, the operating cost statement shall indicate separately any subsidization received by the establishment from the company as a whole, or an individual related establishment, and it shall also show any capital investment from the 
not only greatly facilitate the exposure of indirect price discriminations such as those achieved through cost allocation, but would also encourage suits by private litigants to whom the products of this disclosure would be available.

Working without the proposed legislation, however, injured competitors should not find the problem of discovery insuperable. Once the plaintiff has established a prima facie case by satisfying the court that there is a reasonable possibility that its competitive disadvantage is occasioned by abuse of the dual distribution technique, ${ }^{84}$ the burden could then be placed on the integrated firm to explain the source and justification of its cost allocations. This smoking-out rule would achieve substantially the same result as the proposed legislation while dispensing with the necessity of having every integrated firm file such information.

Another obstacle to effective application of the Act, though not unique to cases of dual distribution, is the actual or threatened retaliatory refusal to deal. This tactic is employed to discourage those injured by the discrimination from bringing suit, to punish those who do, and thereby to deter others from attempting to sue. The privilege of customer selection embodied in the Colgate ${ }^{85}$ doctrine and

retained earnings of the company, a related establishment, or the establishment itself. Section 5 requires that such information be available to the public, either through the annual stockholders' report, or by filing such information with the FTC.

The obvious advantage of such a scheme is that it provides easy access to crucial information by both the private litigant and the federal agencies. However, it may also facilitate price fixing by disclosure of information to competitors. Another difficulty is presented by the fact that many costs within an integrated enterprise are not susceptible to allocation to one establishment or another. For example, the executive officers of the manufacturing establishment may also be executive officers for the wholesale establishment but may have their salaries expensed to the former. The question then becomes what portion of these salaries, if any, should be allocated to the cost structure of the wholesale establishment for the purpose of disclosure. An even more difficult situation is presented by advertising expenditures made by the integrated enterprise on its own behalf and on behalf of the related establishments. To the extent that such items of non-separable cost are prevalent, any attempt at separation of cost data in the fashion contemplated by the proposed amendment is impractical and unrealistic.

84 In determining the content of the prima facie case engendered by the showing of a reasonable possibility of competitive disadvantage, it is necessary to consider and balance conflicting policies: the policy of encouraging harmony within the economic community by avoiding excessive litigation between customers and the policy of providing effective enforcement of the antitrust laws. The difficulty of such an accommodation suggests an ad hoc approach to the problem with the question submitted to the judge for determination on the facts of each case.

${ }_{85} 250$ U.S. 300 (1919). The Colgate Court held that a mere refusal to deal, in the absence of an agreement between the manufacturer and its customers, could not be a 
included in section 2 (a) of the Robinson-Patman Act, ${ }^{86}$ taken literally, would appear to permit such refusals to deal as an effective weapon in the discouragement of private suits under the Act. The scope of the doctrine has, however, been greatly limited by later decisions. ${ }^{87}$ Consequently, there are now several possible methods of limiting the effectiveness of refusals to deal as a deterrent to private litigation while preserving the basic right of customer selection.

Initially, a preliminary injunction may be granted to restrain, pending completion of the litigation, the manufacturer from refusing to deal with the suing distributor. The Second Circuit Court of Appeals in House of Materials, Incorporated v. Simplicity Pattern Company ${ }^{88}$ refused to uphold such an injunction ${ }^{89}$ apparently on the

violation of the Sherman Act, regardless of the reasons underlying the refusal. Id. at 307. However, the refusal to deal was attacked as part of a price maintenance scheme.

Later cases have limited the thrust of the Colgate doctrine by expanding the scope of actionable refusals to deal. In FTC v. Beech-Nut Packing Co., 257 U.S. 441 (1922), where the FTC brought an action under $\$ 5$ of the Federal Trade Commission Act, the Supreme Court upheld the issuance of a cease and desist order because, while there was no express agreement or contract, the "cooperative methods" used to prevent anyone from obtaining Beech-Nut products at less than the suggested retail prices were incompatible with the policies laid down in the Sherman Act. Id. at 454-56. In United States v. Parke, Davis \& Co., 362 U.S. 29 (1960), the Court further restricted Colgate by making such activity a violation of the Sherman Act, thereby establishing a basis for private litigation. The types of cooperative activity deemed unlawful by the courts include: sending out agents to spy on customers, see FTC v. Beech-Nut Packing Co., supra; Q.R.S. Music Co. v. FTC, 12 F.2d 730 (7th Cir. 1926); do-not-sell lists, see United States v. Parke, Davis \& Co., supra; FTC v. Beech-Nut Packing Co., supra; Hills Bros. v. FTC, 9 F.2d 481 (9th Cir.), cert. denied, 270 U.S. 662 (1926); numbering and symbol systems to catch price cutters, see United States v. Parke, Davis \& Co., supra; FTC v. Beech-Nut Packing Co., supra. One circuit court has summed up the present 'state of the law thusly: "The Supreme Court has left a narrow channel through which a manufacturer may pass even though the facts would have to be of such Doric simplicity as to be somewhat rare in this day of complex business enterprise." George W. Warner \& Co. v. Black \& Decker Mfg. Co., 277 F.2d 787, 790 (2d Cir. 1960).

so "Nothing herein contained shall prevent persons ... from selecting their own customers in bona fide transactions and not in restraint of trade." 15 U.S.C. $\$ 13$ (a) (1964).

87 See, e.g., FTC v. Bcech-Nut Packing Co., 257 U.S. 441 (1922); George W. Warner \& Co. v. Black \& Decker Mfg. Co., 277 F.2d 787 (2d Cir. 1960).

ss 298 F.2d 867 (2d Cir. 1962). The case involved an action for treble damages under $\$ 2(e)$ of the Robinson-Patman Act based on an earlier action, FTC v. Simplicity Pattern Co., 360 U.S. 55 (1959), in which the Supreme Court affirmed a cease and desist order against Simplicity for discriminating in services on behalf of larger customers. Upon receiving notice of the suit, Simplicity threatened to drop the plaintiff's franchise. The plaintiff retailer moved for a preliminary injunction restraining the defendant from refusing to deal, alleging that the cancellation was solely a punitive measure intended to coerce the dropping of the suit and to discourage others from suing. The defendant 
theory that the refusal to deal in that case ${ }^{90}$ did not present an appropriate basis for equitable relief.91 Subsequently, however, the Third Circuit Court of Appeals in Bergen Drug Company v. Parke, Davis of Company, ${ }^{92}$ citing Simplicity as authority, ${ }^{93}$ ruled that a temporary injunction could appropriately be granted where refusals to deal were employed to coerce abandonment of a suit.94 Arguably, the narrowness of the holding in Simplicity coupled with its expansive

replied that there was nothing in the antitrust laws to prevent such action, relying on the Colgate doctrine.

${ }^{80}$ The district court in P. W. Husserl, Inc. v. Simplicity Pattern Co., 191 F. Supp. 55 (S.D.N.Y. 1961), rev'd sub nom., House of Materials v. Simplicity Pattern Co., 298 F.2d 867 (2d Cir.1962), had balanced the "strong public policy in favor of permitting private suitors to maintain causes of action for violation of the anti-trust laws both on their own and in the public interest," id. at 62 , against the privilege of customer selection weakened by post-Colgate cases, and held that since the latter was being used "in pursuance of an objective inimical to the purposes and policies of the antitrust laws ...." id. at 63, the former should prevail. The court also dismissed the argument that such a refusal to deal was protected by the customer selection proviso of $\S 2$ (a) of the Act by finding that the defendant's activities were not bona fide transactions.

00 " $[I] \mathrm{n}$ an appropriate case a court might restrain a defendant from attempting to coerce a plaintiff into discontinuing a suit." $298 \mathrm{~F} .2 \mathrm{~d}$ at 871 (dictum).

11 The district court was reversed on the grounds that the refusal to deal was not part of an antitrust violation and that use of the court's general equity power was not proper in this case since the refusal to deal "did not have the legal effect of depriving [plaintiff] of a remedy for past injury." Id. at 872. It would appear that while there is indeed no legal deprivation of the right to sue, the lower court's recognition of the actual discouragement warrants consideration and perhaps provides a sound basis for granting the preliminary relief.

92307 F.2d 725 (3d Cir. 1962).

98 Id. at 727 .

s The defendant had terminated dealings with the plaintiff upon learning that he had instituted a treble damage action. The plaintiff moved for a preliminary injunction which the district court refused. On appeal, the Third Circuit reversed: "We think that the district court, as a court of equity, did possess the power to issue the preliminary injunction." Id. at 726. The court drew an analogy to cases under the Dealers' Day in Court Act, 15 U.S.C. $\$ \$ 1221-25$ (1964), in which it had granted preliminary relief compelling the manufacturer to continue dealing with the plaintiff until the litigation had been concluded. The court also focused upon the importance of private suits in effective enforcement of antitrust regulation: "Private actions are an important means of enforcing the antitrust laws of the United States. Such actions are a vehicle for serving not only the immediate interests of the litigants, but the continuing interest of the public in a smoothly functioning and unobstructed system of commerce. Congress voiced its recoguition of the importance of private actions by enacting special provisions for treble damages and attorneys' fees." Id. at 727-28.

Two provisions in Title 15 of the United States Code expressly aid the private litigant. Section 15, 15 U.S.C. $§ 15$ (1964), formerly 38 Stat. 791 (1914), affords liberal venue provisions, treble damages, no minimum claim requirement, and recovery costs of litigation. Section 16, 15 U.S.C. $\$ 16$ (1964), formerly 38 Stat. 731 (1914), provides that a government judgment is prima facie evidence of a violation, and that the statute of limitations is halted by commencement of the government's suit and for a year thereafter. 
interpretation in Bergen Drug indicate a trend toward greater acceptance of preliminary injunctions to prevent this coercive use of refusals to deal.

Such relief, however, is only temporary in nature and thus does not prevent the seller from refusing to deal after the suit is concluded.95 Although the language of the decisions would seem to ban post-litigation refusals, in practice only those refusals to deal which are part of an antitrust violation have been enjoined by the courts. Moreover, no case involving a private antitrust action has enjoined a refusal to deal with a particular customer. On the other hand, a great number of cases permit refusals to deal which are not appendant to antitrust violations, ${ }^{96}$ but these cases may be distinguished since they involve prospective rather than present customers.

Although present law thus does not deem unlawful a refusal to deal which is not part of an antitrust violation, the injurious effect of retaliatory refusals in these instances would seem to demand judicial attention. To permit a manufacturer to refuse to deal with an independent distributor after the latter had successfully prosecuted a Robinson-Patman suit against him would circumvent the purpose of the Act by making the distributor's victory meaningless and by discouraging future suits by other independent distributors. Consequently, the manufacturer should be permitted to cancel or to refuse to renew the independent distributor's franchise only when a business purpose independent of the desire to punish and deter can be established. ${ }^{97}$ Such an approach would encourage private en-

\footnotetext{
${ }^{95}$ An injunction will apparently be dissolved once the suit is concluded. It is arguable, however, that at this point no reason exists for a continuation of the refusal to deal. All those customers who had causes of action would, by that time, have had the opportunity to sue under the protection of the injunction, thus removing the deterrent effect of a refusal. See Note, 71 Yale L.J. 1564, $1575-76$ (1962).

${ }^{\circ 6}$ See Theater Enterprises, Inc. v. Paramount Film Distrib. Corp., 346 U.S. 537 (1954); Leo J. Meyberg Co. v. Eureka Williams Corp., 215 F.2d 100 (9th Cir.), cert. denied, 348 U.S. 875 (1954); Nelson Radio \& Supply Co. v. Motorola, Inc., 200 F.2d 911 (5th Cir. 1952), cert. denied, 345 U.S. 925 (1953); G. \& P. Amusement Co. v. Regent Theater Co., 107 F. Supp. 453 (N.D. Ohio 1952), aff'd, 216 F.2d 749 (6th Cir. 1954), cert. denied, 349 U.S. 904 (1955); United States v. J. I. Case Co., 101 F. Supp. 856 (D. Minn. 1951); Windsor Theater Co. v. Walbrook Amusement Co., 94 F. Supp. 388 (D. Md. 1950), aff'd, 189 F.2d 797 (4th Cir. 1951); Sorrentino v. Glen.Gery Shale Brick Corp., 46 F. Supp. 709 (E.D. Pa. 1942).

or It has been argued that allowing refusals to deal only when independent business purposes exist would amount to an unwarranted extension of the remedies provided by the antitrust laws: "The District Court appears to have found by implication in
} 
forcement of the antitrust laws while not unduly impinging upon the privilege of customer selection. ${ }^{98}$

Aside from preliminary and post trial injunctive relief, a refusal to deal may be shown to be part of an antitrust violation and thus within the scope of the Parke Davis rule. While it has been argued that refusals to deal constitute the most egregious form of price discrimination, ${ }^{99}$ the Second Circuit in Simplicity found this argument unworthy of discussion. ${ }^{100}$ While the court's inattention may be justifiable insofar as prospective purchasers are involved, ${ }^{101}$ the use of refusals to deal to punish and deter present purchasers can be viewed as an integral part of the manufacturer's plan of price discrimination, since it reduces the possibility of detection and thus enhances the effectiveness of the scheme. ${ }^{102}$ Thus, though retaliatory

Section 4 of the Clayton Act a prohibition against coercing persons who bring treble damage actions to discontinue them. But we think that such an implication is unwarranted, for we find nothing in the language or purpose of the statute which suggests that Congress intended to force manufacturers to deal with persons who sue them, while not forcing them to deal with others." House of Materials, Inc. v. Simplicity Pattern Co., 298 F.2d 867, 871 n.11 (2d Cir. 1962). However, even assuming that Congress did not intend that franchisees could institute a Robinson-Patman action to force the manufacturer to continue dealing with them, that fact should not prevent careful application of the statutory sanctions in those cases in which it is clear that there exists no legitimate business motive other than a desire to punish and deter. By so holding the courts would arguably achieve a realistic balance between the policies embodied in the privilege of customer selection and those embodied in the congressional desire for effective enforcement of the antitrust laws through private enforcement.

${ }^{88}$ It may also be argued that refusals to deal in situations in which no independent business purpose exists constitute an unfair method of competition which may be eliminated under $\S 5$ of the Federal Trade Commission Act, 15 U.S.C. $\$ 45$ (a) (1) (1964). The creation of a public remedy raises the possibility that the courts might extend relief to private individuals in order to ensure comprehensive enforcement of the statutory principles. Cf. FTC v. Beech-Nut Packing Co., 257 U.S. 441 (1922).

${ }^{\circ 9}$ See Comment, 58 YALE L.J. 112], 1133-34 (1949): "[L]ogically complete refusal to sell is only a refusal to sell at any but a prohibitive price. In practice, moreover, a complete refusal to sell can often be used with the purpose and effect of price discrimination .... Since refusals to sell are practically and logically extensions of discriminations in price, discriminatory refusals, like discriminatory sales, should be subjected to the criteria of that section." But see Barber, Refusals to Deal Under the Federal Antitrust Laws, 103 U. PA. L. Rev. 847, 848-51 (1955).

${ }^{100}$ House of Materials, Inc. v. Simplicity Pattern Co., 298 F.2d 867, 871 (2d Cir. 1962).

${ }^{101}$ See Shaw's, Inc. v. Wilson-Jones Co., 105 F.2d 331 (3d Cir. 1939); Wholesale Auto Supply Co. v. Hickok Mfg. Co., 221 F. Supp. 935 (D.N.J. 1963); Sorrentino v. Glen-Gery Shale Brick Corp., 46 F. Supp. 709 (E.D. Pa. 1942).

${ }^{102}$ Another possible theory of regulation lies in a finding that the refusals to deal are part of a contract, see United States v. A. Schrader's Sons, 252 U.S. 85 (1920) (express or implied), combination, see United States v. Parke, Davis \& Co., 362 U.S. 29, 44 (1960), or conspiracy, see United States v. Bausch \& Lomb Optical Co., 321 U.S. 707 (1944), in restraint of trade, in which case treble damages may be awarded. 
refusals to deal appear to present a significant obstacle to effective application of Robinson-Patman to dual distribution, the courts are not without adequate means for controlling them.

\section{Conclusion}

It would appear that since the integrated firm, through dual distribution, is capable of effecting those types of practices and causing those types of anticompetitive effects sought to be prevented by the Robinson-Patman Act, and moreover, since there do not appear to be any insuperable barriers to its effective application, the division should indeed be deemed a purchaser for purposes of the Act. Such a finding in no way implies that the very existence of dual distribution violates the Act but rather only that it will be regnlated in the same manner as other distribution techniques. 